\author{
EDYTA PACZKA \\ ORCID: 0000-0003-4811-8414 \\ Uniwersytet Wrocławski \\ Instytut Nauk Ekonomicznych \\ Zakład Myśli Ekonomicznej
}

\title{
COLLABORATIVE CONSUMPTION \\ I JEJ WPŁYW NA ROZWÓJ PRZEDSIĘBIORCZOŚCI W OBLICZU ZMIAN POKOLENIOWYCH
}

\begin{abstract}
Abstrakt: Wspólna konsumpcja jest jednym z nowych trendów w zachowaniach konsumentów, który uwzględnia alternatywne podejście do zaspokajania potrzeb. Trend ten polega na dostępie do dóbr realizowanym bez konieczności posiadania i przenoszenia praw własności. Celem opracowania jest charakterystyka zmian pokoleniowych determinujących skłonność do angażowania się we wspólną konsumpcję i przyczyniających się do jej rozwoju. Analizie poddano czynniki zwiększające zainteresowanie nabywców z pokolenia Y i Z innowacyjnymi rozwiązaniami w sferze konsumpcji, które stanowią dogodną bazę dla rozwoju wielu form przedsiębiorczej aktywności. Wskazano na zmianę w nastawieniu młodych nabywców, którzy wyżej niż nabywanie i posiadanie rzeczy cenią ich użytkowanie oraz dostrzegają okazje, jakie działania z zakresu konsumpcji kolaboratywnej stwarzają dla kreowania różnorodnych postaci przedsiębiorczości.
\end{abstract}

Słowa kluczowe: konsumpcja wspólna, prosumpcja, pokolenie Y, pokolenie Z

\section{WSTĘP}

W dobie konsumpcjonizmu młode pokolenie poszukuje nowych wzorców konsumpcji, które byłyby świadome i etycznie odpowiedzialne. Następuje ewolucja postaw i zachowań młodych nabywców, którzy odchodzą od jednowymiarowego postrzegania konsumpcji w kategoriach niepohamowanego dążenia do gromadzenia dóbr i dobrowolnie ograniczają swoje potrzeby materialne. Dostrzegalna jest tendencja objawiająca się umiarem i odrzuceniem tradycyjnych wzorów spożycia opartych na zwiększaniu stanu posiadania. Konsumenci reprezentujący postawę hedonistyczną i egoistyczną przekształcają się w konsumentów społecznie i ekologicznie odpowiedzialnych, którzy przejawiają dbałość o jakość życia. Rezygnują z niepotrzebnych zakupów i wybierają dobra, które nie szkodzą środo- 
wisku i nie ograniczają możliwości zaspokojenia potrzeb innych konsumentów. Mają coraz większą świadomość swojego otoczenia, zarówno społecznego, jak i naturalnego, wynikającą z adaptacji zasad zrównoważonego rozwoju. Wykazują się racjonalnością w zaspokajaniu potrzeb, a swoją antykonsumpcyjną postawę manifestują na wiele sposobów, począwszy od upraszczania zachowań nabywczych i ponownego wykorzystywania raz nabytych towarów, poprzez redukcję spożycia, aż po całkowitą rezygnację z nabywania dóbr na rzecz uzyskania do nich dostępu. Wybór alternatywnego modelu konsumpcji stanowiącego przeciwwagę dla modelu opartego na posiadaniu świadczy o zmianie mentalności i stylu życia obecnej generacji, która wyraża chęć równoważenia poziomu konsumpcji.

Celem artykułu jest przedstawienie czynników upowszechnienia koncepcji collaborative consumption i jej wpływu na rozwój przedsiębiorczości. Zaprezentowano istotę konsumpcji wspólnej i przedstawiono niektóre jej formy. Szczególną uwagę zwrócono na zmiany w zachowaniach nabywców z pokolenia Y i Z determinujące upowszechnienie nowych form konsumpcji. Wskazano na rozwój różnych postaci przedsiębiorczej aktywności bazujących na idei współdzielenia. Artykuł ma charakter przeglądowy i powstał na podstawie badań literatury.

\section{ISTOTA KONSUMPCJI KOLABORATYWNEJ}

Współcześni młodzi konsumenci reprezentują istotną siłę nabywczą i decyzyjną. Cechuje ich ogromna ciekawość rynku, obserwacja jego mechanizmów, poszukiwanie i zainteresowanie innowacyjnymi trendami. Aktywność młodego pokolenia przejawia się $\mathrm{w}$ wyznaczaniu kierunku przemian rynkowych i kreowaniu alternatywnych modeli spożycia. Jednym z nich jest konsumpcja kolaboratywna (collaborative consumption), zwana inaczej współpracującą (wspólną) lub ekonomią dzieloną (sharing economy) ${ }^{1}$. Jako nowy trend konsumencki zakłada uzyskanie dostępu do dóbr, ale bez nabycia do nich praw własności. Jak zauważa T. Zalega, jest skoncentrowana na funkcji produktu i korzyściach stąd wynikających, a nie na posiadaniu ${ }^{2}$. Polega na pożyczaniu, wynajmowaniu, umowach barterowych czy też wymianie ${ }^{3}$. Znajduje zastosowanie w różnych dziedzinach ludzkiej aktywności, a do obszarów, w których jest najbardziej rozwinięta, należą: transport, turystyka, zamieszkanie, finanse, jedzenie, ubrania, czas wolny. Przyjmuje różne formy, wśród których do najistotniejszych można zaliczyćt: clothswap, toyswap, czyli wymianę typu „rzecz za rzecz”; couchsurfing, a więc

1 T. Zalega, Nowe trendy konsumenckie jako przejaw innowacyjnych zachowań wspótczesnych konsumentów, „Nierówności Społeczne a Wzrost Gospodarczy” 2016, nr 46, s. 215-216.

2 Ibidem, s. 216.

3 Ibidem.

${ }^{4}$ P. Wardak, T. Zalega, Konsumpcja kolaboratywna jako nowy trend konsumencki, „Studia i Materiały. Wydział Zarządzania UW” 2013, nr 16, s. 10. 
oferowanie bezpłatnego zakwaterowania lub odnajdywanie osób, które oferują darmowy nocleg we własnym domu czy mieszkaniu; homeswapping polegający na zamianie domów i mieszkań między mieszkańcami różnych regionów lub krajów (na przykład na czas urlopu); meal-sharing, czyli zapraszanie do swojego stołu na wspólny posiłek osób, które cenią domową i lokalną kuchnię; carpooling będący formą oferowania przejazdów i korzystania z wolnych miejsc w samochodach (na przykład wspólna jazda do pracy czy szkoły); crowdfunding oznaczający finansowanie społecznościowe różnego typu przedsięwzięć.

Wspólna konsumpcja nie jest zjawiskiem nowym, od dawna ludzie dzielą się bowiem swoimi zasobami. Charakterystyczne jest, że tego typu działania, realizowane początkowo tylko z członkami rodzin czy przyjaciółmi i znajomymi, zaczęto stopniowo podejmować także z nieznanymi sobie wcześniej osobami. Wzrost zainteresowania koncepcją współdzielenia należy tłumaczyć zmianami preferencji, zachowań i oczekiwań współczesnych konsumentów, którzy z uwagi na postępujący krytycyzm wobec dotychczasowych form konsumpcji podejmują świadome decyzje i wybierają opcje korzystniejsze dla środowiska naturalnego. Mają szeroki dostęp do nowoczesnych technologii ułatwiających komunikację i odnajdywanie się osób, które posiadają wolne zasoby, oraz takich, które chciałyby z nich skorzystać. Są otwarci na współpracę, integrację i nawiązywanie bezpośrednich relacji, które nie podlegają bezpośrednio mechanizmom rynku i omijają tradycyjne transakcje firma-klient, między innymi w wyniku spadku zaufania do etycznej strony praktyk biznesowych. Skala konsumpcji wspólnej ciągle się poszerza, co należy wiązać z kryzysem gospodarczym z 2008 roku, który — jak podkreśla A. Koźlak — skłonił wielu nabywców do większego pragmatyzmu i poszukiwania nowych sposobów zaspokajania potrzeb $^{5}$. Wzmógł tendencję do racjonalizacji wydatków i wymusił pewne zmiany adaptacyjne $\mathrm{w}$ postaci rezygnacji z własności na rzecz tańszej i dogodniejszej formy zaspokojenia potrzeb, czyli uzyskania dostępu do produktu i jego funkcjonalności. Jednocześnie pobudził kreatywność ludzi poszukujących możliwości poprawy swojej sytuacji finansowej i zarobienia pieniędzy.

\section{WPŁYW PRZEMIAN POKOLENIOWYCH NA ROZWÓJ KONSUMPCJI WSPÓLNEJ}

Innowacyjne wzory zachowań stymulowane przez dynamiczny postęp w sferze informacji i komunikacji zyskują na popularności zwłaszcza wśród ludzi młodych, poszukujących tanich, wygodnych i efektywnych rozwiązań, a równocześnie pozostających w zgodzie z troską o środowisko. Młodzi nabywcy chętnie

5 A. Koźlak, Sharing economy jako nowy trend społeczno-gospodarczy, „Prace Naukowe Uniwersytetu Ekonomicznego we Wrocławiu" 2017, nr 489, s. 179-180. 
angażują się w działania z zakresu wspólnej konsumpcji, które nie byłyby możliwe bez wzrostu znaczenia technologii mobilnych i społeczności internetowych ułatwiających wzajemne kontakty oraz wymianę zasobów. Aktywni konsumenci wchodzą w bezpośrednie relacje po to, aby dzielić się własnością. Coraz mocniej uwidacznia się wśród nich tendencja do korzystania z pewnych dóbr lub usług w razie potrzeby, a nie nabywania ich na własność. Idea ta sprowadza się do stwierdzenia, że „nie trzeba mieć, by korzystać” i jest realizowana dzięki platformom i aplikacjom, które łączą osoby chcące podzielić się swoimi zasobami z tymi, które są zainteresowane uzyskaniem do nich dostępu. Czynnikiem rozwoju wspólnej konsumpcji jest zatem skłonność do organizowania się i integracji w grupy, dostrzegalna zwłaszcza wśród młodych użytkowników sieci, którzy wykorzystują ją do realizacji swoich potrzeb konsumpcyjnych.

W opracowaniach naukowych wyodrębnia się pokolenie $\mathrm{Y}$ oraz pokolenie $\mathrm{Z}$ jako dwie generacje młodych osób ${ }^{6}$. Pokolenie $\mathrm{Y}$ jest nazywane pokoleniem sieci (net generation) lub pokoleniem milenijnym (millenials). Jak podaje G. Aniszewska, przyszło ono na świat w latach 1980-1994, a w dorosłość wchodziło w okresie gwałtownego upowszechnienia technologii informatycznych, które znacząco zwiększyły skalę komunikacji międzyludzkiej ${ }^{7}$. Nowoczesne technologie zmieniły zachowania ludzi i zintensyfikowały wzajemne, często bezpośrednie interakcje pomiędzy indywidualnymi podmiotami. Rozwój technologiczny postrzegany jako czynnik sprzyjający efektywności mechanizmów rynkowych paradoksalnie ułatwił czy wręcz umożliwił rozwój dóbr, usług i form zawierania transakcji niepodlegających dyktatowi rynku. K. Czernek, D. Wójcik i P. Marszałek za jeden z najważniejszych przejawów opisanej tendencji uznają konsumpcję kolaboratywną, która w znacznie mniejszym stopniu dotyczy akumulacji dóbr, a w większym - integracji i współpracy między podmiotami ${ }^{8}$. Opiera się na oddolnych inicjatywach indywidualnych osób, które udostępniają innym swoje nie w pełni wykorzystane zasoby poprzez platformy internetowe i mobilne aplikacje za opłatą, na zasadzie współdzielenia kosztów, lub bezpłatnie. Dzięki relacjom P2P, czyli „każdy z każdym”, dzielą się nimi i wymieniają bez zaangażowania instytucji pośredniczących (sklepów, banków, agencji). Pokolenie Y doskonale adaptuje i rozumie systemy peer-to-peer, w których sieć komputerowa umożliwia komunikację użytkowników na równorzędnych zasadach. Jego reprezentanci odchodzą od hierarchicznych, sformalizowanych relacji rynkowych w stronę rozproszonych sieci połączonych z sobą jednostek, które wzajemnie świadczą usługi, współużytkują i współdzielą dobra. Dzięki współpracy realizowanej online uzyskują dostęp do dóbr i usług, na przykład

${ }^{6}$ B. Grabiwoda, E-konsumenci jutra. Pokolenie Z i technologie mobilne, Łódź 2019, s. 45.

7 G. Aniszewska, Zmiany pokoleniowe a decyzje i wybory konsumenckie, „Marketing i Rynek” 2015, nr 1, s. 3.

${ }^{8}$ K. Czernek, D. Wójcik, P. Marszałek, Zaufanie w gospodarce współdzielenia, „Gospodarka Narodowa" 2018, nr 3, s. 30. 
hotelarskich czy taksówkowych, na które dotychczas nie było ich stać. Traktują więc to rozwiązanie jako dużo korzystniejsze cenowo niż zakup dóbr na własność i chętnie z niego korzystają. W ten sposób realizują swoje potrzeby i aspiracje bez żadnych ograniczeń ilościowych, jednak w bardziej racjonalny i odpowiedzialny sposób. Mogą doświadczać tego, co oferują różnorodne produkty, przy jednoczesnym pozbyciu się obowiązków i odpowiedzialności wynikającej z własności (na przykład nie jest konieczne ponoszenie kosztów utrzymania, ubezpieczenia czy serwisowania). Zyskują też sposobność zaakcentowania własnej indywidualności między innymi poprzez korzystanie z niestandardowych usług i produktów, których nie są w stanie zapewnić tradycyjne firmy oferujące masową produkcję.

Millenialsi są siłą napędową wspólnej konsumpcji, co potwierdza raport sporządzony przez PwC (Pricewater house Coopers), z którego wynika, że typowy użytkownik platform P2P to człowiek młody, aktywny w mediach społecznościowych i posługujący się nimi nie tylko do komunikowania się i wymiany informacji, lecz także do zaspokajania swoich potrzeb konsumpcyjnych ${ }^{9}$. Jest to pokolenie dużo bardziej elastyczne i ceniące niezależność w większym stopniu od swoich poprzedników. Millenialsi pragną korzystać z możliwości, jakie oferuje im współczesna gospodarka, jednak w bardziej efektywny sposób, który zapewni im korzystanie z dóbr wcześniej niedostępnych ze względu na barierę cenową. Są otwarci na nowe kontakty i bez trudu nawiązują oddolne relacje poprzez globalną sieć komputerową, która integruje nieznanych sobie ludzi wokół określonych idei, przedsięwzięć i projektów. Funkcjonowanie w wirtualnym środowisku jest dla nich normą i obejmuje coraz szerszy zakres aktywności, w tym także korzystanie z zasobów innych użytkowników sieci oraz oferowanie im własnych pomysłów, produktów i usług. To dzięki ich umiejętności współpracy i łatwości w nawiązywaniu kontaktów, wspólna konsumpcja wyszła poza krąg małych społeczności złożonych z członków rodzin, sąsiadów czy znajomych. Rozwinęła się na niespotykaną dotąd skalę, co wymusiło konieczność weryfikacji wiarygodności i uczciwości biorących w niej udział osób. System rekomendacji, ocen i opinii wzmocnił zaufanie uczestników współdzielenia oraz sprawił, że zachowania postrzegane wcześniej jako ryzykowne i budzące obawy o uczciwość w wirtualnym świecie stały się normą i są obecnie powszechnie akceptowane.

Nowe wzory zachowań dostrzegalne są także wśród najmłodszych konsumentów określanych mianem pokolenia Z, iGeneration, Digital Natives czy 9/11 Generation $^{10}$. Przyjmuje się, że pokolenie $\mathrm{Z}$ to osoby urodzone w latach dziewięć-

9 Raport PwC, Wspótdziel i rządż! Twój nowy model biznesowy jeszcze nie istnieje, s. 7, https:// www.pwc.pl/pl/pdf/ekonomia-wspoldzielenia-1-raport-pwc.pdf (dostęp: 24.01.2020).

${ }^{10}$ Ze względu na ograniczone możliwości precyzyjnego określenia ram czasowych dla pokoleń dwa obecnie najmłodsze - Y i Z - często się przenikają. Biorąc pod uwagę największą powtarzalność dat w dostępnych opracowaniach, można przyjąć rok 1995 za początek okresu urodzeń reprezentantów tej generacji. Wyodrębnienie pokolenia $\mathrm{Z}$ jest wynikiem skoku technologicznego 
dziesiątych i później ${ }^{11}$. W odróżnieniu od swoich poprzedników, którzy stopniowo wkraczali w cyfrową rzeczywistość, przenosząc do niej kolejne elementy swojego życia, pokolenie $\mathrm{Z}$ nie zna świata bez Internetu. Jest to generacja, która bardziej niż jakakolwiek inna wdraża i wykorzystuje nowe technologie informacyjne w codziennym życiu. Jej reprezentanci są nieustannie podłączeni do sieci i od najmłodszych lat funkcjonują w dwóch równoległych wymiarach — wirtualnym i realnym, przy czym tym ten pierwszy traktują jako równorzędny, a coraz częściej nadrzędny w stosunku do świata rzeczywistego. Jednym z kluczowych wyróżników tego pokolenia jest silna potrzeba utrzymywania kontaktów i pozyskiwania informacji za pomocą urządzeń mobilnych. Smartfony i tablety służą jego reprezentantom do komunikowania się, a także kształtują na nowo sposób, w jaki realizują oni swoje potrzeby konsumenckie. Rosnąca częstotliwość ich użycia sprawia, że zmianie ulega model konsumpcji osadzony coraz mocniej w wirtualnej rzeczywistości i uwzględniający alternatywne podejście do zaspokajania potrzeb. Młodzi nabywcy korzystający z mobilnych aplikacji mogą w łatwy sposób wymieniać i dzielić się dobrami, a jednocześnie czerpać korzyści finansowe $\mathrm{z}$ ich udostępniania i pomnażać w ten sposób swoje dochody.

Dynamiczny rozwój gospodarki sieciowej oraz towarzysząca mu globalizacja to zjawiska, które ukształtowały pokolenie Z. O ile starsi konsumenci uczestniczyli w tworzeniu obecnego kształtu gospodarki, który na ogół akceptują, o tyle pokolenie Z staje w opozycji do jej współczesnej postaci. Interpretuje ją jako niedoskonałą, szkodzącą społeczeństwu i środowisku oraz pod wieloma względami nieetyczną. Specyfika tego pokolenia polega na tym, że — jednocześnie z krytyką niektórych przejawów globalizacji - jego reprezentanci akceptują efekty tego procesu bardziej niż poprzednicy i w większym stopniu z nich korzystają. Są entuzjastycznie nastawieni wobec możliwości wynikających z komunikacji internetowej i przejmują określone wzory zachowań, korzystając z produktów i marek globalnych. Ten brak spójności w zachowaniach najmłodszych konsumentów jest odzwierciedleniem zjawiska nazwanego przez B. Mroza selektywną adaptacją, które oznacza częściowe przystosowanie i częściowe odrzucenie ${ }^{12}$. Pokolenie Z przejawia największą łatwość korzystania z pozytywnych aspektów globalizacji przy jednoczesnej - wyraźnie zarysowującej się — świadomości jej negatywnych implikacji. Jest wrażliwe na problemy współczesnej gospodarki i sprzeciwia się tym samym mechanizmom, które napędza, kupując towary firm globalnych. Można zatem stwierdzić, że na tle pozostałych grup społecznych jest generacją,

w latach 1990-2000 obejmującego bardzo szybkie rozprzestrzenianie się Internetu i rozwój telefonii komórkowej. Reprezentanci tej generacji są obecnie najszybciej rosnącą grupą konsumentów na świecie, która stanowi 25,9\% globalnej populacji, czyli około 1,9 miliardów osób (o 1,5\% więcej niż pokolenie Y). Szacuje się, że do końca 2020 roku będą stanowić nawet $40 \%$ populacji na największych rynkach, między innymi w USA, Europie czy Chinach. Za: B. Grabiwoda, op. cit., s. 50-51.

11 G. Aniszewska, op. cit., s. 6.

12 B. Mróz, Konsument w globalnej gospodarce. Trzy perspektywy, Warszawa 2013, s. 27. 
która najsilniej odzwierciedla dwie sprzeczne tendencje — naśladownictwa i indywidualizacji. Z jednej strony tworzy najbardziej homogeniczną grupę, ponieważ od najmłodszych lat korzysta z nowych technologii umożliwiających unifikację stylów życia oraz nabywa jednorodne produkty proponowane przez światowe marki. Z drugiej strony oczekuje spersonalizowanych produktów i usług, dostosowanych do indywidualnych potrzeb, które podkreślą jej wyjątkowość i oryginalność. Pragnie wyróżnić się poprzez konsumpcję i wykreować własny, unikatowy wizerunek. Niespójność w zachowaniach nabywców z pokolenia Z przejawia się zatem w stopniowym ujednoliceniu i standaryzacji postaw, przy silnie zarysowującej się potrzebie indywidualizacji i podkreślenia własnej odrębności. Przywiązaniu do tradycyjnych wzorów konsumpcji towarzyszy wzrastające zainteresowanie innowacyjnymi trendami, które dają młodym nabywcom możliwość wyrażenia siebie oraz stosunku do otaczającej ich rzeczywistości.

Istotnym czynnikiem, który wyróżnia pokolenie $\mathrm{Z}$ od innych, jest świadomość zagrożeń politycznych i gospodarczych będących skutkiem ostatniego kryzysu ekonomicznego i wydarzeń z 11 września 2001 roku. Określenie 9/11 Generation nawiązuje do ataków terrorystycznych w USA i następujących po nich wydarzeń, w cieniu których reprezentanci tego pokolenia się wychowywali. Skala terroryzmu i konfliktów zbrojnych oraz reperkusje światowego kryzysu gospodarczego ukształtowały pokolenie Z, które wyróżnia realizm. W przeciwieństwie do optymistycznych i odważnych millenialsów wychowanych na przełomie lat osiemdziesiątych i dziewięćdziesiątych, a więc w okresie pokoju i gospodarczej stabilizacji oraz pozytywnych nastrojów społecznych, iGeneration ma pesymistyczny stosunek do rzeczywistości. Globalne problemy polityczne i gospodarcze objawiające się brakiem stabilności sprawiły, że jego przedstawiciele deklarują niepewność co do swojej przyszłości. Obawiają się o dostępność miejsc pracy, wyrażają niepokój związany ze wzrostem cen i deklarują potrzebę oszczędzania ${ }^{13}$. Oczekują korzystnych cenowo ofert i produktów oraz możliwości wymieniania i dzielenia się tym, co posiadają. Ważnym czynnikiem rozpowszechnienia wśród reprezentantów tego pokolenia zachowań właściwych dla konsumpcji wspólnej jest więc aspekt finansowy. Młode osoby są w dużej mierze zależne od swoich rodziców i świadome ich sytuacji materialnej, którą biorą pod uwagę przy dokonywaniu zakupów. Podważają sens gromadzenia coraz większej ilości dóbr i zadowalają się ich czasowym użytkowaniem. Zamiast koncentrować się na posiadaniu, większą wagę przywiązują do funkcji oraz przeżyć i doświadczeń związanych z konkretnym produktem. Dzięki współdzieleniu mogą nieustannie podążać za modą, mimo że często nie stać ich na zakup najnowszych modeli dóbr.

Zaangażowanie pokolenia $\mathrm{Z}$ we wspólną konsumpcję wynika nie tylko z możliwości zaoszczędzania środków, ale także zyskania na wymianie czy wypożyczaniu za opłatą. Platformy i aplikacje pozwalają na czerpanie korzyści fi-

13 B. Grabiwoda, op. cit., s. 62. 
nansowych konsumentom, którzy są właścicielami określonych dóbr i decydują się na ich udostępnianie. Możliwość uzyskania w ten sposób dodatkowego dochodu jest jednym z czynników zachęcających do uczestnictwa we wspólnej konsumpcji, a zarazem siłą napędzającą jej rozwój. Tendencja ta uwidoczniła się zwłaszcza podczas globalnej recesji spowodowanej ostatnim kryzysem, gdy pojawiły się problemy na rynku pracy, spadły płace, wzrosła niepewność zatrudnienia i bezrobocie. Młodzi uczestnicy rynku dostrzegli wówczas w nowym trendzie szansę na zwiększenie dochodów i siły nabywczej, a także na rozszerzenie swojej aktywności ekonomicznej. Uzyskali tym samym dobrą podstawę do tworzenia rentownych biznesów i z osób czerpiących zyski z dzielenia się własnymi, niewykorzystanymi zasobami przeistoczyli się w przedsiębiorców, których działania polegają na łączeniu za pośrednictwem nowoczesnych technologii posiadaczy dóbr z ich odbiorcami ${ }^{14}$. Jak zauważają P. Wardak i T. Zalega, w ostatnich latach powstało wiele internetowych start-upów prowadzących innowacyjne platformy i oferujących mobilne aplikacje, które ułatwiają udostępnianie i wymianę rzeczy między indywidualnymi podmiotami ${ }^{15}$. Zjawisko to należy wiązać zwłaszcza z aktywnością pokolenia Z, w którego nastawieniu szczególnie mocno uwidacznia się dążenie do samodzielności i prowadzenia własnego biznesu. Mimo że to millenialsi zapoczątkowali ten trend, to jednak reprezentanci najmłodszej generacji w większym stopniu niż ich poprzednicy pragną podążać własną drogą, a sukces zawodowy wiążą nie tyle z karierą w korporacji, co z indywidualną działalnością będącą często odzwierciedleniem zainteresowań czy pasji ${ }^{16}$. Doceniają potencjał tkwiący we wspólnej konsumpcji i upatrują w niej szans na tworzenie innowacyjnych modeli prowadzenia działalności gospodarczej, które mają wpisane w swoją konstrukcję: elementy autonomii działania, szerokiego wyboru czy elastyczności. Są to cechy ważne dla przedstawicieli pokolenia Z, spójne z właściwą dla nich potrzebą swobody i wolności wyboru.

\section{KONSUMPCJA KOLABORATYWNA A PRZEDSIĘBIORCZOŚĆ}

Różnorodne tendencje w zachowaniach współczesnych konsumentów tworzą podatny grunt dla kształtowania się nowych form przedsiębiorczej aktywności. Pole do kreowania innowacyjnych rozwiązań otwiera zwłaszcza wspólna konsumpcja, która skutkuje rozwojem zjawiska prosumpcji. Jak podaje E. Szul, trend ten polega na wzajemnym przenikaniu się konsumpcji i produkcji, aż do zatarcia granic między nimi, w wyniku czego konsumenci stają się jednocześnie przedsiębiorcami,

14 J. Janczewski, Konsumpcja wspótdzielona a przedsiębiorczość, „Przedsiębiorczość — Edukacja” 13, 2017, s. 270.

15 P. Wardak, T. Zalega, op. cit., s. 13.

16 B. Grabiwoda, op. cit., s. 54. 
producentami, dostawcami, gdyż w takiej roli sytuuje ich posiadanie określonych zasobów ${ }^{17}$. Jako prosumenci, a więc konsumenci i producenci w jednym, wykorzystują platformy i aplikacje do udostępnienia innym swoich niezagospodarowanych aktywów (materialnych i niematerialnych), dzięki czemu zwiększają ich wydajność. Niewykorzystane zasoby oddane w czasowe użytkowanie innym osobom mogą zapewnić ich właścicielowi dodatkowy dochód bądź poszerzyć grono jednostek partycypujących w kosztach utrzymania. Idea prosumpcji opiera się zatem na koncepcji konsumpcji innowacyjnej, która nie umniejsza finansów konsumenta, ale przynosi mu dodatkowe korzyści dzięki jego kreatywności. M. Mitręga i O. Witczak traktują prosumpcję jako przejaw konsumenckiej przedsiębiorczości ${ }^{18}$. Rozważają nawet tezę, że prosumpcja jest synonimem przedsiębiorczości w odniesieniu do zachowań konsumenta na rynku.

Rozwój zjawiska prosumpcji jest konsekwencją wielu różnorodnych czynników. Zdaniem T. Zalegi świadczy o rosnącym sprzeciwie ze strony konsumentów wobec masowej produkcji, ujednoliconej i zestandaryzowanej ${ }^{19}$. Nabywcy oczekują spersonalizowanych produktów i interaktywnego charakteru konsumpcji. Pragną, aby dobra były zgodne $\mathrm{z}$ ich wyobrażeniami, dostosowane do indywidualnych upodobań i preferencji, aby podkreślały ich wyjątkowość i oryginalność.

$\mathrm{Z}$ kolei C. Bywalec thumaczy prosumencką aktywność rozwojem edukacji, zmianą organizacji pracy i jej roli w życiu człowieka, wzrostem czasu wolnego i potrzebą jego atrakcyjnego zagospodarowania oraz możliwością wykonywania pracy zawodowej w domu i przeplataniem się jej z konsumpcją ${ }^{20}$. Pod wpływem procesu prosumpcji kształtuje się nowy model życia i styl pracy. Znika tradycyjny podział na czas pracy i czas wolny, a tym samym na pracę oraz wypoczynek wypełniony konsumpcją. W ten sposób czas wolny przestaje być wyłącznie czasem konsumpcji i staje się czasem prosumpcji.

Prosumenci wywodzą się głównie z internetowo-cyfrowego pokolenia, które ma umiejętność współdzielenia się własnością i samoograniczenia prawa do wyłącznego użytkowania rzeczy. Jego przedstawiciele odchodzą od jednowymiarowego uczestnictwa w konsumpcji na rzecz wzmocnienia postaw przedsiębiorczych poprzez oferowanie posiadanych przez siebie zasobów innym osobom, zainteresowanym ich użytkowaniem. Działania prosumenckie inspirowane współdzieleniem polegają na stopniowym przejmowaniu przez konsumentów zadań producentów oraz czerpaniu z tego tytułu korzyści finansowych. Wzrost aktywności konsumenckiej w sferze stanowiącej niegdyś domenę działań przedsiębiorców jest charakterystyczny zwłaszcza dla generacji Z, która poszukuje nowych źródeł

17 E. Szul, Prosumpcja jako aktywność wspótczesnych konsumentów - uwarunkowania i przejawy, „Nierówności Społeczne a Wzrost Gospodarczy” 2013, nr 31, s. 347-348.

18 M. Mitręga, O. Witczak, Prosumpcja jako przejaw przedsiębiorczości konsumenckiej, „Zeszyty Naukowe Uniwersytetu Szczecińskiego" 2012, nr 724, s. 440.

19 T. Zalega, op. cit., s. 208.

20 C. Bywalec, Konsumpcja a rozwój gospodarczy i społeczny, Warszawa 2010, s. 221. 
dochodów oraz jest otwarta na alternatywne formy zatrudnienia (tak zwane samozatrudnienie) i elastyczne modele pracy (wykonywanej okresowo i w niepełnym wymiarze czasu w porównaniu do pracy na etacie). Jej reprezentanci są kreatywni, otwarci na współpracę, chcą działać z pasją i realizować swoje marzenia, nawet za cenę mniejszych dochodów czy braku stabilności finansowej. Teza ta znajduje potwierdzenie w badaniach ankietowych przeprowadzonych wśród 1327 internautów na potrzeby raportu Pracownik przyszłości $i^{21}$, z którego wynika, że dla wielu młodych osób wysokie zarobki nie są tak ważne jak kreatywność w wykonywaniu zadań, na którą wskazał co czwarty badany z pokolenia Z (26\%), podczas gdy na zarobki - tylko co piąty (19\%). Inaczej jest w przypadku millenialsów, którzy przykładają większą wagę do zarobków - co trzeci badany w wieku 23-34 lata docenił ich znaczenie (24\%), a 14\% respondentów wskazało, że wykonywanie obowiązków zawodowych powinno łączyć się z rozwojem posiadanych umiejętności i kwalifikacji. Raport ujawnił też rosnącą niechęć młodego pokolenia do standardowych form zatrudnienia, $w$ tym zwłaszcza do pracy na etacie $\mathrm{w}$ pełnym wymiarze godzin, czego dowodzi niewielka liczba pozytywnych wskazań — tylko $26 \%$ ogółu ankietowanych i $18 \%$ respondentów z pokolenia Z. Młodzi ludzie preferują bardziej elastyczne formy pracy, takie jak telepraca wykonywana zdalnie za pośrednictwem Internetu czy telefonu (analogicznie 21\% i 11\% badanych), ale także te dające większą niezależność i możliwość podejmowania decyzji, jak freelancing (odpowiednio 17\% i 9\%) oraz prowadzenie własnej działalności (19\% i $28 \%$ ).

Zdaniem M. Cicharskiej, P. Styczeń i K. Szaro głównym akceleratorem rozwoju nowych form przedsiębiorczej aktywności bazujących na współdzieleniu jest postęp technologiczny22. Jak zauważa T. Pakulska, rewolucja informatyczna pociągnęła za sobą wiele konsekwencji, które tworzą specyficzne środowisko rozwoju gospodarki ${ }^{23}$. Wzrosło wykorzystanie Internetu i urządzeń mobilnych, niezbędnych ogniw w rozwoju działań zaliczanych do obszaru wspólnej konsumpcji, które zyskały globalny zasięg. Zmienił się kształt relacji biznesowych. Informatyzacja życia przyczyniła się do rozwoju relacji sieciowych z dużą rolą portali społecznościowych. Przestrzeń działania postrzegana w kategoriach przestrzeni internetowej stworzyła dogodne warunki dla wprowadzania innowacji poprzez nowe możliwości pozyskiwania informacji, nowe zasady wymiany i transakcji oraz interakcji z otoczeniem. Współautorami innowacji stali są klienci, a w miarę wzrostu znaczenia ICT (technologie informacyjne i telekomunikacyjne) społeczność internetowa, która może uczestniczyć w procesie ich finansowania

${ }^{21}$ Pracownik przyszłości, Gdańsk 2019, s. 16-19, https://images.samsung.com/is/content/sam sung /p5/pl/pracownik/pracownik_przyszlosci_2019infuturesamsung.pdf?_ga=2.148243253.3604 12905.1574439829-1813242068.1573040464 (dostęp: 24.01.2020).

22 M. Cicharska, P. Styczeń, K. Szaro, op. cit., s. 96.

23 T. Pakulska, Otoczenie przedsiębiorstw a rozwój sharing economy, [w:] Sharing economy. Modele biznesowe. W stronę równości czy rozwarstwienia, Warszawa 2018, s. 96. 
i realizacji projektu (crowdfunding, crowdsourcing). Do powszechnego użytku weszły proste $\mathrm{w}$ obsłudze aplikacje, które umożliwiają pozyskiwanie informacji o produktach, porównywanie ofert oraz dotarcie do dóbr i usług bez konieczności ich zakupu na własność. Cyfryzacja stworzyła większe możliwości dla przedsiębiorczości poprzez zmniejszenie barier wejścia dla nowych podmiotów. Uproszczeniu uległy transakcje finansowe przeprowadzane online, a elektroniczne formy płatności i rozliczeń stały się powszechne. W wyniku tych zmian nastąpił rozwój alternatywnych form zaspokajania potrzeb, które otworzyły pole do kreowania nowych biznesów oferujących innowacyjne usługi polegające na łączeniu za pośrednictwem technologii posiadaczy dóbr z ich odbiorcami. Nowoczesne platformy i aplikacje pełnią rolę pośrednika i kojarzą osoby, które chcą skorzystać z określonych zasobów, z ich właścicielami. Ułatwiają dotarcie do dóbr i usług bez potrzeby ich nabycia na własność, co skłania coraz więcej osób do użytkowania oraz tworzenia platform i aplikacji.

\section{PODSUMOWANIE}

Rozwój konsumpcji wspólnej jest odzwierciedleniem zmian zachodzących w mentalności, systemie wartości i zachowaniach współczesnych nabywców, którzy rezygnują z posiadania, dzięki czemu konsumują taniej i w bardziej wygodny sposób. Wielu z nich postrzega własność nie w kategoriach przywileju, lecz niekorzystnego dla nich zobowiązania. Konsumenci, szczególnie młodzi, nie lubią przywiązywać się do rzeczy, skoro za chwilę pojawią się nowsze i lepsze. Dzięki wspólnej konsumpcji mogą nie tylko doświadczać tego, co oferują im różnorodne produkty bez wielu niedogodności wynikających z własności, ale też zastępować stare rzeczy nowymi bez szkody dla środowiska naturalnego. Nowy trend zapewnia im uzyskanie relatywnie szybkiego i łatwego dostępu do nowinek technicznych czy droższych produktów. Umożliwia też utrzymanie wysokiego poziomu zaspokojenia potrzeb nawet wówczas, gdy znajdują się w trudnej sytuacji finansowej.

Rozwiązania z zakresu wspólnej konsumpcji stwarzają dogodne warunki dla zakładania internetowych biznesów, które pośredniczą w procesie udostępniania zasobów. Przedsiębiorczość oparta na wspólnej konsumpcji obejmuje nie tylko osoby podejmujące ryzyko organizacji nowego biznesu (dostawcy platform i aplikacji), lecz również tych, którzy do niego przystępują, oferując swój czas, umiejętności, posiadane aktywa. Działalność tego typu bazuje na aktywizacji zasobów, które nie były wcześniej wykorzystywane lub tylko w ograniczonym zakresie i stanowią własność konsumentów, którzy decydują się na ich efektywne zastosowanie. Animatorami takich przedsięwzięć są zwłaszcza przedstawiciele najmłodszej generacji, którzy jako prosumenci dzielą się swoją własnością i czerpią z tego tytułu korzyści finansowe. Stają się kreatorami konsumpcji innowacyjnej i przed- 
siębiorczej, która łączy się z ich inwencją twórczą i aktywnością gospodarczą oraz jest źródłem dochodów.

\title{
COLLABORATIVE CONSUMPTION AND ITS INFLUENCE ON THE DEVELOPMENT OF ENTREPRENEURSHIP IN THE FACE OF GENERATION CHANGE
}

\begin{abstract}
Summary
Collaborative consumption is one of the new trends in consumer behaviour that takes into account an alternative approach to satisfying one's needs. This trend is based on access to goods realised without the need to possess and transfer property rights. The purpose of the paper is to characterise generational changes determining the willingness to engage in collaborative consumption and, therefore, impacting its popularisation. The author analysed factors increasing consumers' (belonging to the $\mathrm{X}$ and $\mathrm{Y}$ generation) interest in innovative solutions in the sphere of consumption, which constitute a favourable base for the development of many forms of entrepreneurial activities. Attention was paid to the changes in the attitude of young purchasers who value the actual usage of things more than making the purchase and possession of those items, and who recognise opportunities that the collaborative consumption-related activities provide for the creation of various forms of entrepreneurship.
\end{abstract}

Keywords: collaborative consumption, prosumption, generation $\mathrm{Y}$, generation $\mathrm{Z}$

\section{BIBLIOGRAFIA}

Aniszewska G., Zmiany pokoleniowe a decyzje i wybory konsumenckie, „Marketing i Rynek” 2015, nr 1 , s. 2-7.

Bywalec C., Konsumpcja a rozwój gospodarczy i społeczny, Warszawa 2010.

Cicharska M., Styczeń P., Szaro K., Sharing economy. Modele biznesowe. W stronę równości czy rozwarstwienia, Warszawa 2018.

Czernek K., Wójcik D., Marszałek P., Zaufanie w gospodarce wspótdzielenia, „Gospodarka Narodowa" 2018, nr 3, s. 23-48.

Grabiwoda B., E-konsumenci jutra. Pokolenie Z i technologie mobilne, Łódź 2019.

Janczewski J., Konsumpcja współdzielona a przedsiębiorczość, „Przedsiębiorczość — Edukacja” 13, 2017, s. 262-274.

Koźlak A., Sharing economy jako nowy trend społeczno-gospodarczy, „Prace Naukowe Uniwersytetu Ekonomicznego we Wrocławiu" 2017, nr 489, s. 171-182.

Mitręga M., Witczak O., Prosumpcja jako przejaw przedsiębiorczości konsumenckiej, „Zeszyty Naukowe Uniwersytetu Szczecińskiego" 2012, nr 724, s. 431-444.

Mróz B., Konsument w globalnej gospodarce. Trzy perspektywy, Warszawa 2013.

Pakulska T., Otoczenie przedsiębiorstw a rozwój sharing economy, [w:] Sharing economy (gospodarka wspótdzielenia), red. M. Poniatowska-Jaksch, R. Sobiecki, Warszawa 2016, s. 39-53.

Pracownik przyszłości, Gdańsk 2019, https://images.samsung.com/is/content/samsung/p5/pl/pracownik/ pracownik_przyszlosci_2019infuturesamsung.pdf?_ga=2.148243253.360412905.15744398291813242068.1573040464 (dostęp: 24.01.2020).

Przegląd Prawa i Administracji CXX, 2020, cz. 1 i 2

(C) for this edition by CNS 
Raport PwC, Współdziel i rządź! Twój nowy model biznesowy jeszcze nie istnieje, https://www.pwc. $\mathrm{pl} / \mathrm{pl} / \mathrm{pdf} /$ ekonomia-wspoldzielenia-1-raport-pwc.pdf (dostęp: 24.01.2020).

Szul E., Prosumpcja jako aktywność współczesnych konsumentów - uwarunkowania i przejawy, „Nierówności Społeczne a Wzrost Gospodarczy” 2013, nr 31, s. 347-358.

Wardak P., Zalega T., Konsumpcja kolaboratywna jako nowy trend konsumencki, „Studia i Materiały. Wydział Zarządzania UW" 2013, nr 16, s. 7-32.

Zalega T., Nowe trendy konsumenckie jako przejaw innowacyjnych zachowań wspótczesnych konsumentów, „Nierówności Społeczne a Wzrost Gospodarczy” 2016, nr 46, s. 202-225. 